DC 140

. D95

Copy 1 



\title{
THE AUTHORSHIP OF THE JOURNAL D'ADRIEN DUQUESNOY
}

\author{
By FRED MORROW FLING
}

REPRINTED FROM THE

\section{American gristontial gentraw}


.

1. 


\section{THE AUTHORSHIP OF THE JOURNAL D'ADRIEN DUQUESNOY}

Wно was the author of the work bearing the title Journal d'Adrien Duquesnoy'? ${ }^{1}$ The editor, M. de Crèvecœur, inferring, from what seemed to him sufficient evidence, that the writer was Duquesnoy, gave this title to the publication. M. Brette, on the contrary, declares that the evidence is insufficient to justify the inference. The question of authorship still remains unsettled. It is a question of the first importance for students of the French Revolution, for the work is one of the most valuable sources dealing with the events of the National Assembly.

The Journal is one of the publications of the Societte d'Histoire Contcmporaine, and was edited, as I have said, by M. de Crèvecœur. M. de la Sicotière, who was a member of the society, had in his possession a series of letters and bulletins written between June I3, I 789, and March 22, I 790. The letters, few in number, were in the handwriting of Duquesnoy, and were signed by him; the bulletins, with the exception of a few autograph corrections by Duquesnoy, were the work of copyists. This evidence, together with the fact that in his letters Duquesnoy referred to "his bulletins," seemed to justify the inference that he was the author of the bulletins found with the letters. While preparing the bulletirs for the press, M. de Crèvecœur encountered in the Bibliothèque Nationale an anonymous manuscript in two volumes containing bulletins covering the period from May 3, I789, to April 3, I790. The bulletins, from June $\mathrm{I} 3$ on, proved to be duplicates of the bulletins in the Sicotière manuscript. M. de Crèvecœur inferred, naturally, that Duquesnoy was the author of this series also, and fused the two series in his publication and called the work the Journal d'Adrien Duquesnoy. ${ }^{2}$

The work was reviewed by M. Brette. ${ }^{3}$ Overlooking the statement of the editor that some of the bulletins in manuscript $\mathrm{S}$. bore autograph corrections by Duquesnoy, he asserted that the discovery

${ }^{1}$ Duquesnoy, Adrien, Journal d' Adrien Duquesnoy, Député du Tiers État de Barle-Duc, sur l'Assemblée Constituante, 3 mai 1789-3 avril 179o, publiè pour la Société d' Historre Contemporaine par Robert de Crèvecaur. 2 vols., Paris, 1894.

2 Journal, I. pp. xvii, xviii, xxxvi-xl.

${ }^{3}$ Revue Critique, May I1, I896, pp. 363-373. 
of the letters in the midst of the bulletins did not prove that $\mathrm{Du}$ quesnoy was the author of the bulletins. He also pointed out that while the publication was a correct reproduction of the manuscript B. no variants were given. He recalled the fact that M. de la Sicotière had stated in I $\$ 85$ that these bulletins and letters that he attributed to Duquesnoy began in December, 1788 , and ended in May, I 790, and asked why M. de Crèvecœur had not published them all. ${ }^{1}$ While not believing in the authorship of Duquesnoy, M. Brette does not attempt to solve the question of authorship. $\mathrm{He}$ suggests that the bulletins may have been the work of anonymous writers of nouvelles a la main, of a M. Bernard or of a M. Fiscal, but hardly seems to take these suggestions seriously himself.

As to the hypothesis that the Journal belongs to the class of newspapers called nouvelles à la main, the evidence upon which it rests appears to me of but little value. M. Brette laid great stress upon the fact that in the manuscript B.- the only one that he has seen - the bulletins are not all in the same handwriting, and, above all, that the writing changes often at the foot of the page, even when such a change divides a sentence. Upon the first point I shall not dwell. I am acquainted with no law that enables me to decide how many copyists a man may reasonably employ at the same time - unless it be the length of his purse - nor how often he may reasonably change them. Upon the changes in the middle of a sentence or at the bottom of the page, I shall say a word. I have examined the manuscript B. ${ }^{2}$ As far as I was able to discover, the sudden changes are found only in bulletins 8 and 9 , and each bulletin shows two handwritings. Hardly sufficient evidence, one would think, to justify the statement that "these methods savor of the workshop of the nonvelles." ${ }^{3}$ The truth is that the hand-

II the Revue Critique of June 22, I896, M. Guilhiermoz, who had aided M. de Crèvecœeur in the revision of his proofs, replied to M. Brette and gave a satisfactory answer to this question. In a note printed in the Intermédiaire, M. de la Sicotière bad made the statement that led M. Brette to assume that the manuscript had been tampered with. "La réalité est beaucoup plus simple: c'est la note de l' Intermédiaire qui est erronée. . . . M. de la S. a sans doute écrit mars, et l'imprimeur de l' Intermédiaire aura $l_{1}$ mai." Prefixed to the mauuscript $S$. are "quelques lettres, sans aucun rapport avec le Jou'nal, et relatives à l'Assemblée des notables."

"Bibliothèque Nationale, Nouvelles Acquisitions Frangaises, Nos, 224, 225. The manuscript fills volumes XIV. and XV. of the Notes sur. l' Histoire d'Expagne et de France. This main bead appears upon the title page with the subhead, Correspondance sur l'Assemblee Nationale. In the printed volumes, the matter is divided at the same point as in the manuscript.

3 “ Le manuscrit B. dont il nous donne le texte in extenso présente cette particularité que les écritures qui, pour le tome I, ne doivent pas être au nombre de plus de cinq ou six, sont alternatives et changent, non pas avec les bulletins, nou pas avec les dates, mais avec les pages mêmes; le copiste ne finit pas la phrase; il a èté payé pour écrire tant de pages, il passe la main quand sa tache est remplie. Ces procédés sentent bien, on en conviendra, l'oficine des nouvelles." Revue Critique, May II, ISg6. 
writing counts for very little in determining the authorship of these bulletins. As every student of the French Revolution knows and no one better than M. Brette - the members of the Assembly were accustomed, especially in 1789 , to send letters and bulletins to their constituents and friends in the provinces. Not only were copyists employed in the preparation of these bulletins, but after the bulletins reached the provinces they were often copied a second time that they might serve a larger number of readers. ${ }^{1}$ It is quite within the bounds of possibility that there are copies of copies among the bulletins in the manuscript B. For M. Brette to lay so much stress upon the fact that the bulletins are not in the handwriting of Duquesnoy, is certainly not reasonable, although the reason for his course is clear; it is the evidence upon which M. de Crèvecœur rests his case. M. Brette was certainly right in maintaining that the evidence was insufficient; he was wrong in believing, as he apparently does, that the case can be won only with that kind of evidence. $^{2}$ It is strange that he should not have seen that authorship is not necessarily dependent upon penmanship.

The theory that Bernard is the author of the Sicotière bulletins from December 9, 1789, on, because these bulletins are in his handwriting, is easily disposed of. The author of the bulletin of December IO, was a member of the Assembly. ${ }^{3}$ Bernard was not a member of the Assembly and must, therefore, have copied the bulletin, as it appears in his handwriting. If he copied one, he may have copied more than one, or in other words, all that appear in his handwriting.

M. Brette's third hypothesis that a certain M. Fiscal may be the unknown author of the bullctins, is no more tenable than the other two. It evidently rests upon the misinterpretation of a sentence in one of Duquesnoy's autograph letters. Writing to the Prince, he says: "M. Bernard takes my bulletins and has them sent to you ; he tells me that you have received those of M. Fiscal." 4 M. Brette assumes that Fiscal was a writer of bulletins. Why not a receiver of bulletins? Is it not quite possible that what Duquesnoy meant to say was, "He tells me that you received from M.

1 The second volume of the ITie et Correspondance of Gaultier de Biauzat, published by Francisque Mège ( 2 vols. Paris, 1890 ), is a good illustration of this kind of work. See pp. 46, 51, 57, 73, 79, 80, 88, IOo, I01, I09, I49, 163, 164, and especially 209.

2 " Il reconnaitra aussi que des doutes sérieux subsisteront sur l'attribution globale qui a èté faite tant que l'on n'aura pas prouvé par l'écriture que tous ces bulletins sont l'culvre du seul Duquesnoy.', Revue Critique, June 22, I $\$ 96$.

3 “Mon projet n'est pas de l'examiner en détail, car je stis si frappé de l'inconvénient dont je viens de parler que jamais je ne pourrai voter pour son adoption." Journal, II. 156 .

Journal, II. I50. 
Fiscal the bulletins that I sent to him?" Fiscal could not have been the author of these bulletins, for the author was a member of the Assembly. In M. Brette's excellent lists of the members of the Constituent Assembly, there is no Fiscal. To M. Brette, Fiscal was an obscure person who might have been the writer of nouvelles à la main. Fiscal was not so obscure as M. Brette thinks. Princes, a hundred years ago, did not have letters addressed to them par la voie of obscure persons. ${ }^{1}$ If M. Brette wishes to find M. Fiscal, he should look for him not in Paris, but in the place where the Prince of Salm-Salm was residing in November, I 789 .

The remaining objections of $M$. Brette to the authorship of Duquesnoy rest upon other grounds than those that we have been considering. The writer makes incorrect statements. It is the opinion of M. Brette that Duquesnoy could not have been ignorant of these things. Here we are in the region of uncertainties. What is the test? Duquesnoy was from Nancy and Nancy is in Lorraine. If the writer of the bulletins should refer several times to Nancy as a city of Provence, the inference would be natural that the writer could not be Duquesnoy. Unfortunately, the facts cited by M. Brette are not of this kind and there might be a justifiable difference of opinion as to whether Duquesnoy could be ignorant of them and remain Duquesnoy." I believe that, in face of the strong positive reasons that will be given in support of the authorship of Duquesnoy, we must infer that he was ignorant.

Up to the present time, much of the discussion upon this question of authorship has been irrelevant. A restatement of the question may render its solution less difficult. Whatever may be the relations between manuscripts $S$. and $B$., it is generally agreed that the published work is a correct reproduction of the manuscript $\mathrm{B}^{3}$ Furthermore, there is no reason to doubt the genuineness of this manuscript. It was undoubtedly written in the years 1789 and 1790. The handwriting being that of copyists, proves nothing as to authorship. Is it possible from the study of this manuscript, aided by all the resources at our disposal, to determine the authorship of these bulletins? I believe that it is. If it be not, then historical criticism is but a useless theory, for never was there a more promising opportunity for it to prove its practical value.

I "Il est étonnant que vous n'ayez pas reçu les lettres qui vous ont été adressées par la voie de M. Fiscal. M. le comte m'assure qu'elles peuvent être retardées, mais qu'elles ne seront point égarées, parce qu'il est sûr de lui." Joumal, II. II. Bernard to SalmSalm.

${ }^{2}$ Revue Critique, June 22, 1896, p. 370.

3 “ La publication actuelle faite en conséquence de la découverte signalée est la reproducti ın scrupuleuse et correcte du inuscrit conservé à la Bibliothèque nationale dans les papiers de Beauchamps.', M1 Brette in the f'ezue Critique, Mlay II, IS96. 
I shall endeavor to show (I) that the bulletins are related to one another, that is, are by the same man ; (2) what the personality of the writer was, and (3) that this personality fits Duquesnoy and nobody else. I shall not examine all the bulletins. M. Brette denies that Duquesnoy was the author of the May and June bulletins of I789. I shall endeavor to show that he was. To prove that he was the author of later bulletins, it is only necessary to show that they are connected, either directly or indirectly, with these first bulletins.

The bulletins form a series. This is made clear by such references as "the preceding number," 1 "one of the preceding numbers," 2 "the present number," 3 " a future number ;" ${ }^{4}$ by references to previous bulletins by number as "Number I 3," "Number 44." ${ }^{6}$ This last reference, found in bulletin 46 , of July I I, I 789, would seem to prove that the author began to issue the bulletins at the opening of the States General.

The author also refers to his bulletins as "my journal," " but in the same sentence refers to the "number" of the journal that he is writing. In another place he speaks of his work as "being less a gazette, a recital of facts, than a series of observations upon the facts." 8

These bulletins are not intended for the general public, but for the friends of the writer in one of the provinces. He urges them to read a certain bulletin with care and "to preserve it until time and events shall have destroyed or fortified " his fears. ${ }^{9} \mathrm{He}$ frequently warns them against the false reports that circulate in the provinces, and reminds them that one who is on the spot can secure more reliable information. ${ }^{10}$ He sends to them in printed form the speeches, decrees, memoirs, and other matter to which he has referred in his bulletins. ${ }^{11}$

These things, however, although they prove the existence of a connected series of bulletins, do not prove that all the bulletins in the manuscript B. primarily formed part of the series. There is a presumption in favor of it; nothing more.

${ }^{1}$ Bulletins 2, 14, 2 I (35, in order, but not numbered).

2 Bulletin 28 .

${ }^{3}$ Bulletin 10.

* Bulletin 39 .

5 Bulletin 14.

${ }^{6}$ Bulletin 46.

i "Je place ici, comme je l'ai fait dans tout le cours de mon journal, un numéro destiné aux observations et dans lequel je ne garde pas l'ordre rigoureux des faits." Bulletin 34 (bis).

${ }^{8}$ Bulletin 46 .

9 Bulletin Io.

${ }^{10}$ Bulletins 10, 15, 21, 24.

"1 Bulletins 3, 6, 7, 13, 16, 19, 39 . 
The connection between some of the bulletins can be established by means of language. In the first bulletin-a very short one-he writes: "Je pense, et je ne suis pas le seul, que le gouvernement veut nous prendre par famine et par lassitude." The first sentence of the next bulletin reads: "L'opinion qu'on veut prendre les députés par ennui ou par famine attache chaque instant davantage." The appearance of the same idea in both bulletins, expressed in almost identical language, would seem to indicate common authorship. In bulletin 10 is the uncommon expression, "Une fureur de parler inconcevable!" This expression is met with again in bulletin $\mathrm{I} 4$, in the form, "Tous ont la fureur de parler," and finally in an autograph letter by Duquesnoy it appears again in the phrase, "La fureur de parler que vous nous connaissez." I Is the expression sufficiently unique to justify the inference that these two bulletins had a common author and that that author was Duquesnoy? I am somewhat familiar with the literature of the Revolution, but if I have encountered the expression in any other writer, I have forgotten it. The very unique expression, "Délibérer quatre jours sur l'aile d'une mouche," is found in bulletins 10 and $\mathrm{I} 2$; it would seem to bind them to each other and to bind $\mathrm{I} 2$ to 14 . The language employed in 2 (p. 4) and in 10 (p. 3o), in describing the sermon of the bishop of Nancy, connects 2 with IO and, consequently, with I 2 and $\mathrm{I} 4$.

Language is, however, not the only nor is it the most important means employed in binding the bulletins together. The continuity of the narrative, the references to statements in earlier bulletins, judgments upon men and events, personal sentiments, personal interests and associations, all these things point to a common author. In dealing with these topics, we are at the same time forming a conception of the personality of the writer. Instead of grouping the matter under these different heads, I shall adopt a more practical method of presentation, treating the bulletins in their order and showing some of the possible connections.

The connection between bulletins $\mathrm{I}$ and 2 is established by the language referred to above, by a reference in number 2 to an incorrect statement in $\mathrm{I}$, and by the fact that the bulletins deal with the events of successive days and form a continuous narrative. Bulletin 3 takes up the narrative where 2 leaves it. There is, also, a reference in 3 to the "sermon de l'évêque" that would be intelligible only to a reader of 2 . The remarks made in numbers 5 and 6 upon Necker's speech, connect those bulletins with 3 . The opening sentence in 4 marks that bulletin as a continuation of 3 .

${ }^{1}$ Joumal, I. 85 . 
The two expressions quoted above connect 4 with 10 ; another expression connects it with $8 ;{ }^{1}$ a reference to Mirabeau's journal connects it with 8 and through $S$ with $I O$; indications that the writer is from Lorraine and interested in that province connects the bulletin with 5, 6, I0, I I, I2, I3 14 , I6, 20, 2 I, 22, 24, 3 I, 45. The opinion expressed upon the Bretons in 4 , connects the bulletin with 5,7, IO, I 3, I 5, I 8, 28. A reference to the "règlentent" binds 4 to 5. The bulletin 5 has been connected with 3 and 4 ; it is connected with 6 by the use of similar expressions in both. ${ }^{2}$ The bulletin 6 is connected with 4 by common expressions $;^{3}$ with 3 by a common opinion $;^{4}$ with 7 by the reference to the Duc de Praslin and by the same bond with 9 and 10 . The description of Target connects 9 with IO. The bulletin $I 7$ is bound to 16 by the references to the "projet de conciliation," and to I 3 by the reference to Rabaud de Saint-Etienne and the Protestant religion. Number I9 is connected with I 8 by the reference to the garde des sceaut $x$, and the substance of 19 is reproduced, with many identical expressions, in Duquesnoy's autograph letter of the same date. The reference to the Duc de Mortemart binds 23 to 20, while the belief expressed in Mirabeau's venality connects 23 with 24 . Bulletin 25 is connected with $24,22,26$, and $27 . .^{5}$ The reference to the clergy binds 29 to 27 . Number 30 is connected, by the judgments expressed upon Necker, with $7,8,9,10,34$, and 34 (bis). The reference to Maury, binds 32 to $3 \mathrm{I}$. The reference to the intrigues of the nobles, connects 33 with 34 . The reference to Bouche connects 36 with 31 ; 37 is connected with 36 by the reference to the meeting of the bureaux, with ${ }_{3} 8$ by the reference to the Duc d'Orléans; the reference to Bailly connects 38 with 39 ; the second paragraph in 40 clearly connects it with 39. These references constitute but a small part of those that might be given. They are sufficient, however, to show that it is highly probable that the first forty builetins form a connected series and must have been the work of one man.

What was the personality of the writer? He was a member of the Third Estate, ${ }^{6}$ representing Barrois $;{ }^{7}$ he sent his bulletins to

${ }^{1}$ Bulletin 4 , "Cet homme est une bête féroce " ; bulletin 8 , "De quel droit cette bête féroce, etc ",

${ }^{2}$ Bulletin 5 , "Le moment de l'orage approche" ; bulletin 6, " Il est éviđent que le moment de la crise approche."

${ }^{3}$ The reference to the plan to " faire dissoudre les États, pour entrainer le ministre dans leur chute."

t The opinion upon the views of Necker.

5 With 22, by the reference to Dupont and the Bretons; with 24 , by the reference to the motion of Sieyès; with 26 and 27 by the reference to the Duc d'Orléans.

${ }^{6}$ The references here are too numerous for citation. Even a casual reading must make it clear that the bulletins are the work of a deputy of the Third Estate. See, however, bulletins $4,6,8,9,10,12,14,15,16,17,18.19,20$ and $3_{3}^{8}$.

${ }^{7}$ Bulletin 6, "Nous nous sommes plaints d'une démarche faite sous le nom du Barrois sans son aveu." 
Lorraine $;^{1}$ he was on most intimate terms with the deputies from Nancy $;{ }^{2}$ he made special mention of the words and deeds of persons known in Lorraine ${ }^{3}$ he was a member of the comité des subsistances. ${ }^{4}$

There was, in the Assembly, but one man to whom this description applied; that man was Adrien Duquesnoy. He was born at Briey in Barrois, and represented that place in the National Assembly. Some years before 1789 , he had moved to Nancy, where he became a member of the socićte libre des sciences, arts et belles-lcttrcs and also of the Conseil de Commerce. ${ }^{5}$ In the Assembly, he was a member of the comité des subsistances. ${ }^{6}$ Finally, he was a writer of bulletins. $^{7}$

If $I$ have succeeded in my effort to connect the bulletins, if I have correctly described the personality of the writer, and have stated exactly the facts of Duquesnoy's life, then it would seem to follow, with a high degree of probability, that Duquesnoy must have been the author of the first forty bulletins.

Fred Morrow Fling.

${ }^{1}$ See the references to Lorraine given above.

2 Bulletins 4, 6, 16, 24 .

${ }^{3}$ See the references to Lorraine given above.

${ }^{4}$ Bulletins 27, 39, 40.

5 Joumal, I. pp. xviii-xx.

6 Procès-verbal de l'Assemblie Nationale, I., No. 2, p. 4, the name of Duquesnoy appears in the list as representing the généralité of Lorraine.

${ }^{7}$ Journal, I. 172. 
LIBRARY OF CONGRESS

00196027324 